\title{
DIFFERENT METHODS OF EQUILIBRIUM MOISTURE CONTENT DETERMINATION
}

\section{RAZLIČITE METODE ODREĐIVANJA RAVNOTEŽNOG SADRŽAJA VLAGE}

\author{
Monika LUTOVSKA*, Vangelce MITREVSKI ${ }^{* *}$, Ivan PAVKOV ${ }^{3}$, Mirko BABIĆ $^{* * *}$, \\ Vladimir MIJAKOVSKI ${ }^{* *}$, Tale GERAMITCIOSKI ${ }^{* *}$, Zoran STAMENKOVIC $^{* * *}$ \\ *Faculty of Technical Sciences, University „Mother Teresa” 1000 Skopje, Macedonia \\ E-mail: monika.lutovska@unt.edu.mk \\ ** University "St. Kliment Ohridski”, Faculty of Technical Sciences, 7000 Bitola, Macedonia \\ ${ }^{* * *}$ University of Novi Sad, Faculty of Agriculture, Trg Dositeja Obradovica, 21000 Novi Sad, Republic of Serbia
}

\begin{abstract}
In this paper, a faster and easier way, in comparison with classical methods, to determine the equilibrium moisture content in food materials is shown. The equilibrium moisture content is determined only experimentally, with determination of sorption isotherms. However, the key issue that is a condition for application of certain experimental method for determining of sorption isotherms is the reliability of experimental data obtained for equilibrium moisture content, as well as the time required to determine specific sorption isotherm. Despite numerous advantages of the static gravimetric method, the long time to achieve equilibrium moisture content of the sample is its main drawback and reason why the researchers use other techniques and methods. Out of these reasons came the idea to apply relatively fast and simple method to determine equilibrium moisture content in food materials, based on the values of average material temperature change obtained from experiments including convective drying kinetics. Furthermore, the resulting temperature response from the conducted experiments can be successfully used to determine unknown parameters in the models for calculation of equilibrium moisture content, by applying of inverse approach method that is an essential tool in modeling of heat and mass transfer processes for different food materials.
\end{abstract}

Key words: equilibrium moisture content, inverse method, pear, quince

\section{REZIME}

U ovom radu je prikazan brži i jednostavniji, u odnosu na klasične metode, način za određivanje ravnotežne vlažnosti kod prehrambenih materijala. Ravnotežni sadržaj vlage, određuje se jedino eksperimentalnim putem, pomoću određivanja sorpcionih izotermi. Međutim, ključno pitanje koje je uslov za korišćenje određene eksperimentalne metode za određivanje sorpcionih izotermi pouzdanost dobivenih eksperimentalnih podataka, kao $i$ vreme potrebno da se utvrdi određena izoterma sorpcije. Pored brojnih prednosti koje ima statički gravimetrijski metod, dugi period za postizanje ravnotežnog sadržaja vlage je glavni nedostatak zbog čega istraživači koriste druge tehnike i metode za postizanje ravnoteže. Iz navedenih razloga, nastala je ideja da se, na relativno brz $i$ jednostavan način, odredi ravnotežna vlažnost kod prehrambenih materijala na osnovu vrednosti promene srednje temperature materijala dobivene tokom realizovanih eksperimenata kinetike konvektivnog sušenja primenom inverznog postupka. Eksperimentalna istraživanja obavljena su u laboratorijskoj konvektivnoj sušari sa reprezentativnim uzorcima izabranog voća, kruške i dunje, u širokom opsegu promene temperature vazduha za sušenje $\left(30^{\circ} \mathrm{C}, 40^{\circ} \mathrm{C}, 50^{\circ} \mathrm{C}, 60^{\circ} \mathrm{C}\right.$ i $\left.70^{\circ} \mathrm{C}\right)$ i brzina vazduha za sušenje $(1 \mathrm{~m} / \mathrm{s}, 1,5 \mathrm{~m} / \mathrm{s}$ i $2 \mathrm{~m} / \mathrm{s})$. Na ovaj način, dugotrajna i neprecizna merenja za određivanje ravnotežne vlažnosti statičkom gravimetrijskom metodom za isto voće, na temperaturi vazduha od $15^{\circ} \mathrm{C}, 30^{\circ} \mathrm{C}, 45^{\circ} \mathrm{C}$ i $60^{\circ} \mathrm{C}$, u opsegu od aktivnosti vode $a_{w}=0,112 \div$ 0,920, zamenjeni su jednostavnim merenjima promena temperatura osušenih uzoraka. Dobijeni temperaturni odgovor iz izvedenih eksperimenata, može se dalje uspešno koristiti za određivanje nepoznatih parametara u modelu za izračunavanje ravnotežnog sadržaja vlage, korišćenjem inverznog postupka koji je neophodan alat za modeliranje procesa prenosa toplote $i$ mase različitih prehrambenih materijala.

Ključne reči: ravnotežni sadržaj vlage, inverzni metod, kruška, dunja.

\section{INTRODUCTION}

Solving contemporary scientific problems involves simultaneous use of theoretical and experimental research, wherein the performed experimental research has been used to obtain database and for verification of different mathematical models. Equilibrium moisture content is one of the fundamental parameters, which value is determined only experimentally, by determination of sorption isotherms (Lutovska et al., 2016). However, the key issue that is a condition for application of certain experimental method for determining of sorption isotherms is the reliability of experimental data obtained for equilibrium moisture content, as well as the time required to determine specific sorption isotherm. In other words, the determining sorption isotherms method has been primarily chosen depending on its accuracy, simplicity, stability, range of data obtained, the type of material, time required for measurement and cost (Rahman, 2009a).

Despite numerous advantages of static gravimetric method, the long time to achieve equilibrium moisture content of the sample is its main drawback and reason why researchers use other techniques and methods that require shorter period of time to achieve the equilibrium state. Out of these reasons came the idea to apply relatively fast and simple way to determine equilibrium moisture content in food materials, based on the data of change in mean material temperature obtained from the 
experiments in convective drying kinetics. The experiments were conducted on a convective laboratory dryer (Pavkov, 2012) with representative samples of pear and quince, in a wide range of drying air temperature changes $\left(30,40,50,60\right.$ and $\left.70{ }^{\circ} \mathrm{C}\right)$ and drying air velocity changes (1, 1.5 and $2 \mathrm{~m} / \mathrm{s}$ ) (Mitrevski et al., 2015b). In this way, time consuming and inaccurate measurements for determination of equilibrium moisture content obtained by the static gravimetric method for the same fruit samples, at temperatures of $15,30,45$ and $60{ }^{\circ} \mathrm{C}$ and in range of water activity $\mathrm{a}_{\mathrm{w}}=0.112 \div 0.920$, were replaced by accurate and easy to perform single thermocouple temperature measurements.

The objectives of this study were: 1 . To replace the time consuming and inaccurate measurements for determination of equilibrium moisture content, obtained by the static gravimetric method, by accurate and easy to perform single thermocouple temperature measurements, and 2. To use the resulting temperature response from conducted convective drying experiments in order to successfully determine the unknown parameters in the models for calculation of the equilibrium moisture content, by applying of inverse approach method, when the model is incorporated in the mathematical variable boundary model, or when it is used only for approximation of experimental values of equilibrium moisture content of pear and quince.

\section{MATERIAL AND METHOD}

Two types of experimental research have been realized for this paper. In the first type, the kinetics of convective drying on representative chosen pieces of fruit - pear and quince is investigated, while in the second type, the sorption isotherms of the same fruits are determined. An experimental convective dryer is used for realization of experimental research of the kinetics of convective drying, and a measuring chain in according to recommendations of COST 90 standards (Wolf et al., 1985) has been performed for experimental determination of sorption isotherms.

Fruits used in experimental research are maintained at a temperature of $4{ }^{\circ} \mathrm{C}$ and relative humidity of $75 \%$, while special attention is paid to its selection, especially their size and maturity. Pear is of the variety "William", with an average weight of $180 \div 240 \mathrm{~g}$, average maturity and yellow - green colour that turns red at some parts. The average initial moisture content of representative samples taken from the soft tissue of pear slices is $81.66 \%$ wet basis. Quinces are of the variety "Champion" with light yellow color, average weight $285 \div 385 \mathrm{~g}$ and an average initial moisture content of $80.49 \%$ wet basis. Fresh fruits used in experimental determination of sorption isotherms were peeled and sliced into thin slices in order to obtain uniform samples with thickness of $2 \pm 10^{-1} \mathrm{~mm}$, while for realization of a particular experiment of the kinetic of convective drying fruits were sliced into teen sheets with a thickness of $4 \pm 10^{-1} \mathrm{~mm}$. Then, the soft fruit tissue in a central region, where the cell structure is more uniform, is reduced to a cylinder form with a diameter of $29 \pm 10^{-1} \mathrm{~mm}$. Several measurements were made using a caliper and only samples with a tolerance of $\pm 5 \%$ were used (Mitrevski et.al., 2014).

\section{Static gravimetric method}

The most preferred experimental methods for sorption isotherm determination are (Gal, 1981; Rahman, 2009a): colligative properties method, gravimetric, manometric, hygrometric and other methods. Gravimetric methods are based on achieving equilibrium state of samples with his atmosphere of known humidity, which is defined as a mechanical and thermal equilibrium (Gal, 1981). There are two types of gravimetric methods:

- method with continuous registration of mass sample changes (static systems - isopiestic method, dynamic and evacuated systems) and

- method with discontinuous registration of mass sample changes (static, dynamic and evacuated systems).

Static gravimetric method is the most simple and commonly used method for sorption isotherm determination in many food materials (Saravacos et al., 1986; Tsami et al., 1990; Kiranoudis et al., 1993; Maroulis et al., 1988; Veltcehev et al., 2000; Guine et al., 2002; Kaya et al., 2007; Kaymak-Ertekin and Gedik, 2004; Lahsasni et al., 2002; Lahsasni et al., 2004; Shivhare et al., 2004; Moreira et al., 2008; Blahovec and Yanniotis, 2009; Djendoubi et al., 2011; Djendoubi et al., 2013; Aktas, et al., 2014; Mitrevski et al., 2015). Minimal costs for realization of experimental research, the possibility of determining the equilibrium moisture content of the material in a wide range of relative air humidity at a certain temperature, the simplicity of the method and easy operability are the main advantages of this method compared to the others.

Despite its advantages, the static gravimetric method has numerous disadvantages:

- long experimental periods for achieving equilibration of the samples (several weeks or months) which can result in deterioration of their physical and chemical stability (Saravacos et al., 1986; Mulet et al., 1999; Al-Muhtaseb et al., 2004; Goula et al., 2008; Mitrevski et al., 2015),

- microbiological instability of the material, especially at high values of water activity, $\mathrm{a}_{\mathrm{w}}>0.6$, which needs a small quantity of crystalline thymol in order to prevent microbial spoilage of the samples,

- fluctuating ambient conditions because of the gravimetric measurement of samples performed at a definite time period until constant weight is established (opening the desiccators, taking the sample and returning it again causes significant disturbance which may lead to $20 \%$ error in measured values),

- inability to cover the full range of relative air humidity in the range of $0 \div 1$ with saturated salt solutions (it is always impossible to find salts that could be used for each and every water activity ranging from 0 to 1 ) and

- existence of problems in equilibrium moisture content determination for values of water activity in the range of $0.01 \div 0.02$.

Standard measurement procedure for sorption isotherm determination with selected reference system (reference material, standardized sorption apparatus and evaluation of results) has been defined within the project COST 90 (Wolf et al., 1985).

The initial and equilibrium moisture content of the samples were determined gravimetrically by drying in a laboratory oven at a temperature of $105{ }^{\circ} \mathrm{C}$ and atmospheric pressure for a period of $24 \mathrm{~h}$, until completely dry.

Ten saturated salt solutions $\mathrm{LiCl}, \mathrm{CH}_{3} \mathrm{COOK}, \mathrm{MgCl}, \mathrm{K}_{2} \mathrm{CO}_{3}$, $\mathrm{Mg}\left(\mathrm{NO}_{3}\right)_{2}, \mathrm{NaBr}, \mathrm{SrCl}_{2}, \mathrm{NaCl}, \mathrm{KCl}$, and $\mathrm{BaCl}_{2}$ prepared according to the recommendation of Greenspan (Greenspan, 1977), were used to give defined constant water activity from 0.112 to 0.920 (Mitrevski et al., 2015). 
Experiments of convective drying kinetics

The experiments were conducted on a laboratory convective dryer with representative samples of pear (Mitrevski et al., 2014) and quince (Mitrevski et al., 2015b), in a wide range of drying air temperature changes $\left(30,40,50,60\right.$ and $\left.70^{\circ} \mathrm{C}\right)$ and drying air velocity changes (1, 1.5 and $2 \mathrm{~m} / \mathrm{s})$.

In order to achieve the desired stationary conditions of drying air flow, for certain regime to be realized, an experimental dryer was started one hour before. Three replications were made at every drying regime for each experiment. The drying air temperature, which value is hold constant during one experiment, was measured using two K-type micro-thermocouples placed before entering the chamber or before the dried samples. Material temperature change over time, $t_{x}=0$, is calculated as average arithmetic value of temperatures measured by three microthermocouples placed in the center of selected samples. The average value of drying material temperature has been calculated based on the values obtained by three replications for each regime separately. The average moisture content change of the dried samples is an average arithmetic value from the results obtained by the three replicated measurements of a particular drying regime.

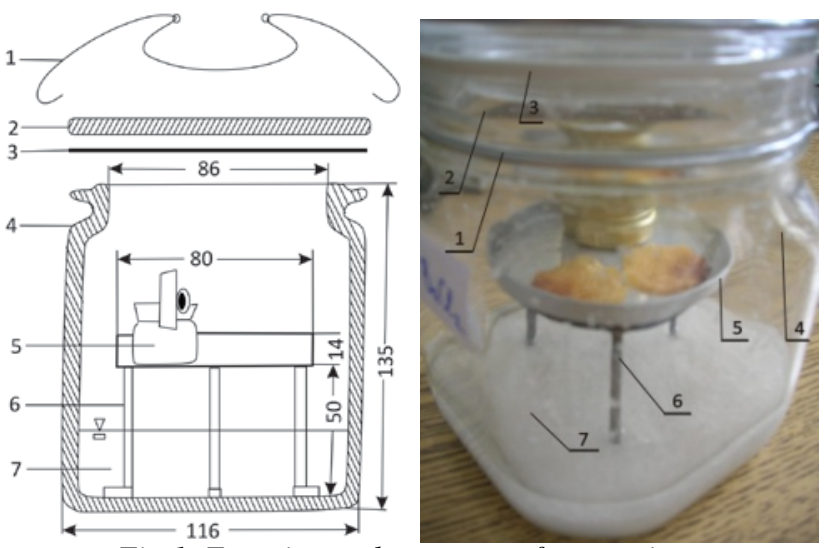

Fig.1. Experimental apparatus for sorption isotherms determination

1 - locking clamp; 2 - lid glass; 3 - rubber seal ring; 4 sorption container; 5 - weighing bottle; 6 - Petri dish on trivet;

7 - saturated salt solution (Spiess and Wolf, 1987)

\section{RESULTS AND DISCUSSION}

Experimental data base for equilibrium moisture content of pear and quince for four different temperatures, 15, 30, 45 and $60^{\circ} \mathrm{C}$ and water activities from 0.110 to 0.920 has been obtained.
Table 1. Equilibrium moisture content of pear

\begin{tabular}{||c|c|c|c|c|c|c|c||}
\hline \multicolumn{2}{|c|}{$\mathbf{1 5}^{\mathbf{0}} \mathbf{C}$} & \multicolumn{2}{|c|}{$\mathbf{3 0}^{\mathbf{}} \mathbf{C}$} & \multicolumn{2}{|c|}{$\mathbf{4 5}^{\mathbf{0}} \mathbf{C}$} & \multicolumn{2}{|c|}{$\mathbf{6 0}^{\mathbf{0}} \mathbf{C}$} \\
\hline $\begin{array}{c}a_{w} \\
{[-]}\end{array}$ & $\begin{array}{c}u_{r} \\
{[\mathrm{~kg} / \mathrm{kg}]}\end{array}$ & $\begin{array}{c}a_{w} \\
{[-]}\end{array}$ & $\begin{array}{c}u_{r} \\
{[\mathrm{~kg} / \mathrm{kg}]}\end{array}$ & $\begin{array}{c}a_{w} \\
{[-]}\end{array}$ & $\begin{array}{c}u_{r} \\
{[\mathrm{~kg} / \mathrm{kg}]}\end{array}$ & $\begin{array}{c}a_{w} \\
{[-]}\end{array}$ & $\begin{array}{c}u_{r} \\
{[\mathrm{~kg} / \mathrm{kg}]}\end{array}$ \\
\hline 0.113 & $0.011 \pm 0.000$ & 0.113 & $0.007 \pm 0.000$ & 0.112 & $0.008 \pm 0.000$ & 0.110 & $0.009 \pm 0.001$ \\
\hline 0.234 & $0.018 \pm 0.000$ & 0.216 & $0.016 \pm 0.001$ & 0.195 & $0.018 \pm 0.000$ & 0.160 & $0.014 \pm 0.002$ \\
\hline 0.333 & $0.040 \pm 0.001$ & 0.324 & $0.040 \pm 0.000$ & 0.311 & $0.040 \pm 0.000$ & 0.293 & $0.031 \pm 0.003$ \\
\hline 0.432 & $0.083 \pm 0.001$ & 0.432 & $0.080 \pm 0.001$ & 0.432 & $0.074 \pm 0.001$ & 0.432 & $0.070 \pm 0.002$ \\
\hline 0.559 & $0.159 \pm 0.000$ & 0.514 & $0.119 \pm 0.000$ & 0.469 & $0.091 \pm 0.002$ & 0.440 & $0.074 \pm 0.002$ \\
\hline 0.607 & $0.197 \pm 0.002$ & 0.560 & $0.145 \pm 0.002$ & 0.520 & $0.107 \pm 0.000$ & 0.497 & $0.090 \pm 0.003$ \\
\hline 0.741 & $0.325 \pm 0.001$ & 0.691 & $0.250 \pm 0.000$ & 0.640 & $0.172 \pm 0.001$ & 0.580 & $0.130 \pm 0.002$ \\
\hline 0.756 & $0.350 \pm 0.002$ & 0.751 & $0.320 \pm 0.003$ & 0.745 & $0.265 \pm 0.000$ & 0.745 & $0.235 \pm 0.001$ \\
\hline 0.859 & $0.600 \pm 0.001$ & 0.836 & $0.495 \pm 0.001$ & 0.817 & $0.395 \pm 0.002$ & 0.803 & $0.335 \pm 0.001$ \\
\hline 0.920 & $0.904 \pm 0.003$ & 0.900 & $0.813 \pm 0.002$ & 0.880 & $0.653 \pm 0.002$ & 0.840 & $0.597 \pm 0.001$ \\
\hline \hline
\end{tabular}

$*$ mean and standard deviation based on $n=3$ replications

Table 2. Equilibrium moisture content of quince

\begin{tabular}{|c|c|c|c|c|c|c|c||}
\hline $\mathbf{1 5}^{\mathbf{0}} \mathbf{C}$ & \multicolumn{3}{|c|}{$\mathbf{3 0}^{\mathbf{0}} \mathbf{C}$} & \multicolumn{2}{c|}{$\mathbf{4 5}^{\mathbf{}} \mathbf{C}$} & \multicolumn{2}{c||}{$\mathbf{6 0}^{\mathbf{0}} \mathbf{C}$} \\
\hline $\begin{array}{c}a_{w} \\
{[-]}\end{array}$ & $\begin{array}{c}u_{r} \\
{[\mathrm{~kg} / \mathrm{kg}]}\end{array}$ & $\begin{array}{c}a_{w} \\
{[-]}\end{array}$ & $\begin{array}{c}u_{r} \\
{[\mathrm{~kg} / \mathrm{kg}]}\end{array}$ & $\begin{array}{c}a_{w} \\
{[-]}\end{array}$ & $\begin{array}{c}u_{r} \\
{[\mathrm{~kg} / \mathrm{kg}]}\end{array}$ & $\begin{array}{c}a_{w} \\
{[-]}\end{array}$ & $\begin{array}{c}u_{r} \\
{[\mathrm{~kg} / \mathrm{kg}]}\end{array}$ \\
\hline 0.113 & $0.008 \pm 0.000$ & 0.113 & $0.013 \pm 0.001$ & 0.112 & $0.009 \pm 0.002$ & 0.110 & $0.010 \pm 0.003$ \\
\hline 0.234 & $0.023 \pm 0.000$ & 0.216 & $0.038 \pm 0.001$ & 0.195 & $0.030 \pm 0.002$ & 0.160 & $0.021 \pm 0.001$ \\
\hline 0.333 & $0.050 \pm 0.001$ & 0.324 & $0.057 \pm 0.003$ & 0.311 & $0.041 \pm 0.003$ & 0.293 & $0.037 \pm 0.001$ \\
\hline 0.432 & $0.093 \pm 0.001$ & 0.432 & $0.087 \pm 0.002$ & 0.432 & $0.076 \pm 0.002$ & 0.432 & $0.063 \pm 0.003$ \\
\hline 0.559 & $0.149 \pm 0.000$ & 0.514 & $0.113 \pm 0.002$ & 0.469 & $0.090 \pm 0.002$ & 0.440 & $0.071 \pm 0.002$ \\
\hline 0.607 & $0.180 \pm 0.002$ & 0.560 & $0.130 \pm 0.000$ & 0.520 & $0.102 \pm 0.002$ & 0.497 & $0.081 \pm 0.001$ \\
\hline 0.741 & $0.295 \pm 0.001$ & 0.691 & $0.224 \pm 0.002$ & 0.640 & $0.158 \pm 0.002$ & 0.580 & $0.110 \pm 0.001$ \\
\hline 0.756 & $0.320 \pm 0.002$ & 0.751 & $0.293 \pm 0.003$ & 0.745 & $0.242 \pm 0.003$ & 0.745 & $0.220 \pm 0.001$ \\
\hline 0.859 & $0.492 \pm 0.001$ & 0.836 & $0.450 \pm 0.001$ & 0.817 & $0.354 \pm 0.001$ & 0.803 & $0.306 \pm 0.001$ \\
\hline 0.920 & $0.799 \pm 0.003$ & 0.900 & $0.715 \pm 0.002$ & 0.880 & $0.599 \pm 0.002$ & 0.840 & $0.565 \pm 0.003$ \\
\hline \hline
\end{tabular}

$*$ mean and standard deviation based on $n=3$ replications

The change in samples' mass was measured every 7 days. The equilibrium between samples and their environment was reached after 21 days as evidenced by the constant weight after two successive weighing of the samples. The measurements were replicated three times for a given temperature and relative humidity. The equilibrium moisture content was calculated as an arithmetic mean of the values obtained from the three measurements. Obtaining the full sorption isotherm at a certain temperature, requires period of several weeks and months. In figure 2 the sorption isotherms of pear at temperature of 15,30 , 45 and $60{ }^{\circ} \mathrm{C}$ are shown, while in figure 3 the sorption isotherms of quince at the same temperatures are shown.

From the diagrams, it can be noticed that an increase in air drying temperature resulted in decreased values of equilibrium moisture content for a constant value of water activity (Lutovska et al., 2016a). For values of water activity over 0.85 for pear, and over 0.80 for quince, the isotherm curves intersect each other (Mitrevski et al., 2015). The point of intersection of the sorption isotherms depend on the structure of the food material, as well as the type and distribution of sugar quantity in the material (Weisser, 1985). Similar results were reported in literature for isotherms of quince exposed to pre-treatment with ultrasonicosmotic dehydration (Noshad et al., 2013), and for the sorption isotherms of some various fruits (Lutovska et al., 2014): prickly pear (Lahsasni et al., 2003; Barroca et al., 2005), apple (Roman et al., 1982; Saravacos et al., 1986) raisins, fig, plum and apricot (Maroulis et al., 1988; Tsami et al., 1990), grape and apricot (Kaymak-Ertekin and Gedik, 2004), mango (Falade et al., 2003). 


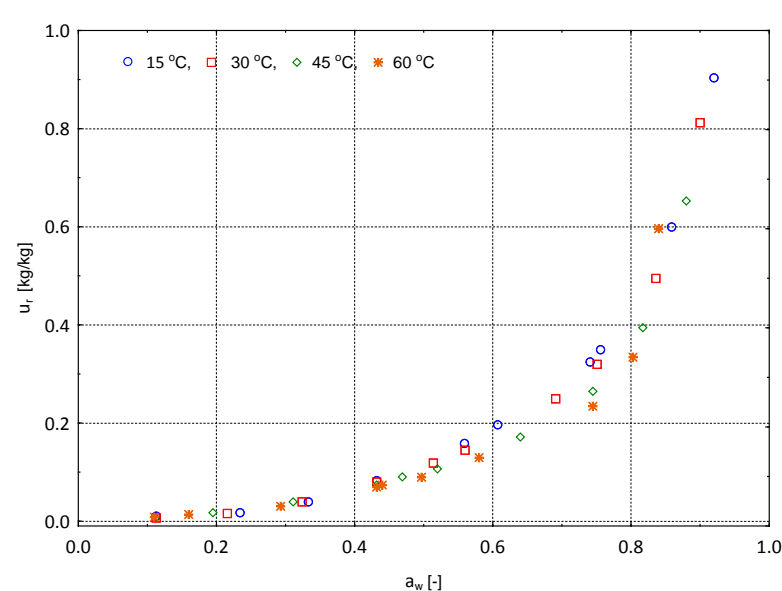

Fig.2. Sorption isotherms of pear

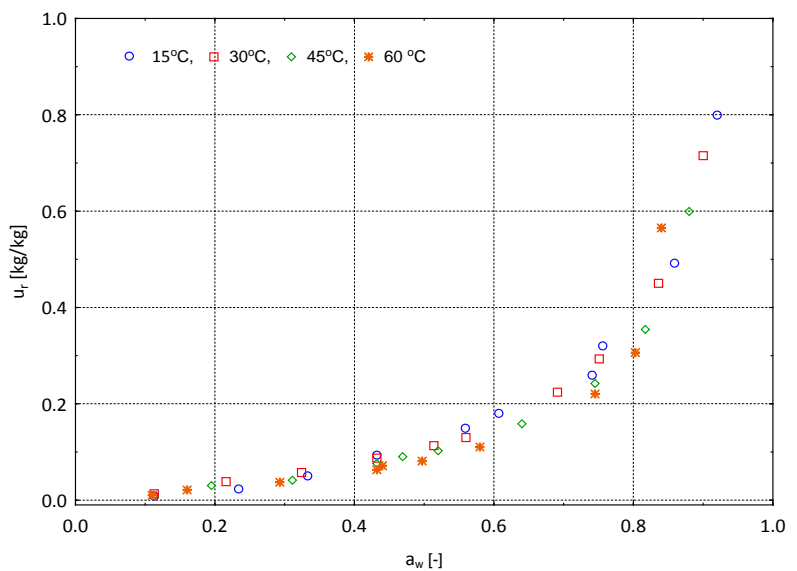

Fig.3. Sorption isotherms of quince

Unlike the time consuming and inaccurate measurements obtained by the static gravimetric method, in the convective drying kinetics experiments, the temperature response needed to obtain the unknown parameters in the sorption models for moisture content determination, is obtained for a much shorter time period. It took 4 hours for drying regime at a temperature of $70{ }^{\circ} \mathrm{C}$, and up to 24 hours for a regime at temperature of $30{ }^{\circ} \mathrm{C}$, respectively, to perform one experiment. A total of 45 drying experiments for pear and 45 drying experiments for quince were performed. Table 3 gives an overview of the performed convective drying kinetics experiments of pear, while Table 4 gives the realized convective drying kinetics experiments of quince.

Table 3. Experimental conditions of pear

\begin{tabular}{|c|c|c|c|c|c|c||}
\hline \hline Experiment & $t_{\text {vsr }}\left[{ }^{\circ} \mathrm{C}\right]$ & $v[\mathrm{~m} / \mathrm{s}]$ & $\tau[\mathrm{min}]$ & $t_{0}\left[{ }^{\circ} \mathrm{C}\right]$ & $\begin{array}{c}u_{0} \\
{[\mathrm{~kg} / \mathrm{kg}]}\end{array}$ & $u_{k}[\mathrm{~kg} / \mathrm{kg}]$ \\
\hline E1.1 & 30.44 & 1.0 & 1350 & 18.18 & 4.73 & 0.05 \\
\hline E1.2 & 30.32 & 1.5 & 1290 & 18.75 & 4.84 & 0.15 \\
\hline E1.3 & 30.34 & 2.0 & 1200 & 17.99 & 4.83 & 0.16 \\
\hline E1.4 & 40.66 & 1.0 & 580 & 19.19 & 4.98 & 0.23 \\
\hline E1.5 & 39.60 & 1.5 & 560 & 19.31 & 4.98 & 0.23 \\
\hline E1.6 & 40.34 & 2.0 & 500 & 19.10 & 4.95 & 0.20 \\
\hline E1.7 & 50.57 & 1.0 & 450 & 19.32 & 5.12 & 0.23 \\
\hline E1.8 & 50.84 & 1.5 & 400 & 19.70 & 5.15 & 0.21 \\
\hline E1.9 & 50.77 & 2.0 & 350 & 19.90 & 5.18 & 0.27 \\
\hline E1.10 & 60.00 & 1.0 & 380 & 19.88 & 5.68 & 0.25 \\
\hline E1.11 & 60.10 & 1.5 & 350 & 19.45 & 4.77 & 0.12 \\
\hline E1.12 & 59.86 & 2.0 & 320 & 19.89 & 4.96 & 0.22 \\
\hline E1.13 & 70.79 & 1.0 & 300 & 19.56 & 4.54 & 0.12 \\
\hline E1.14 & 70.82 & 1.5 & 250 & 19.93 & 4.79 & 0.17 \\
\hline E1.15 & 71.02 & 2.0 & 220 & 19.99 & 4.96 & 0.16 \\
\hline
\end{tabular}

Table 4. Experimental conditions of quince

\begin{tabular}{|c|c|c|c|c|c|c|}
\hline Experiment & $t_{\text {vsr }}\left[{ }^{\circ} \mathrm{C}\right]$ & $v[\mathrm{~m} / \mathrm{s}]$ & $\tau[\mathrm{min}]$ & $t_{0}\left[{ }^{\circ} \mathrm{C}\right]$ & $\begin{array}{c}u_{0} \\
{[\mathrm{~kg} / \mathrm{kg}]}\end{array}$ & $u_{k}[\mathrm{~kg} / \mathrm{kg}]$ \\
\hline E2.1 & 30.61 & 1.0 & 1200 & 18.03 & 4.88 & 0.27 \\
\hline E2.2 & 30.52 & 1.5 & 1080 & 17.72 & 5.08 & 0.29 \\
\hline E2.3 & 30.45 & 2.0 & 990 & 16.42 & 4.69 & 0.17 \\
\hline E2.4 & 40.78 & 1.0 & 500 & 19.99 & 5.23 & 0.22 \\
\hline E2.5 & 40.54 & 1.5 & 480 & 19.87 & 5.42 & 0.25 \\
\hline E2.6 & 40.67 & 2.0 & 460 & 20.01 & 4.59 & 0.22 \\
\hline E2.7 & 50.51 & 1.0 & 320 & 20.10 & 3.99 & 0.12 \\
\hline E2.8 & 50.32 & 1.5 & 300 & 20.01 & 4.52 & 0.20 \\
\hline E2.9 & 50.30 & 2.0 & 280 & 20.11 & 4.70 & 0.29 \\
\hline E2.10 & 60.56 & 1.0 & 300 & 21.01 & 4.85 & 0.14 \\
\hline E2.11 & 60.82 & 1.5 & 280 & 20.50 & 4.91 & 0.29 \\
\hline E2.12 & 60.52 & 2.0 & 260 & 20.40 & 4.62 & 0.23 \\
\hline E2.13 & 70.61 & 1.0 & 280 & 20.56 & 5.27 & 0.36 \\
\hline E2.14 & 70.41 & 1.5 & 220 & 20.12 & 5.10 & 0.33 \\
\hline E2.15 & 69.74 & 2.0 & 200 & 20.30 & 4.97 & 0.24 \\
\hline
\end{tabular}

One of the performed experiments of convective drying kinetics (mean moisture content change and mean temperature change in the center of the samples during time period) of pear pieces is shown in Figure 4.

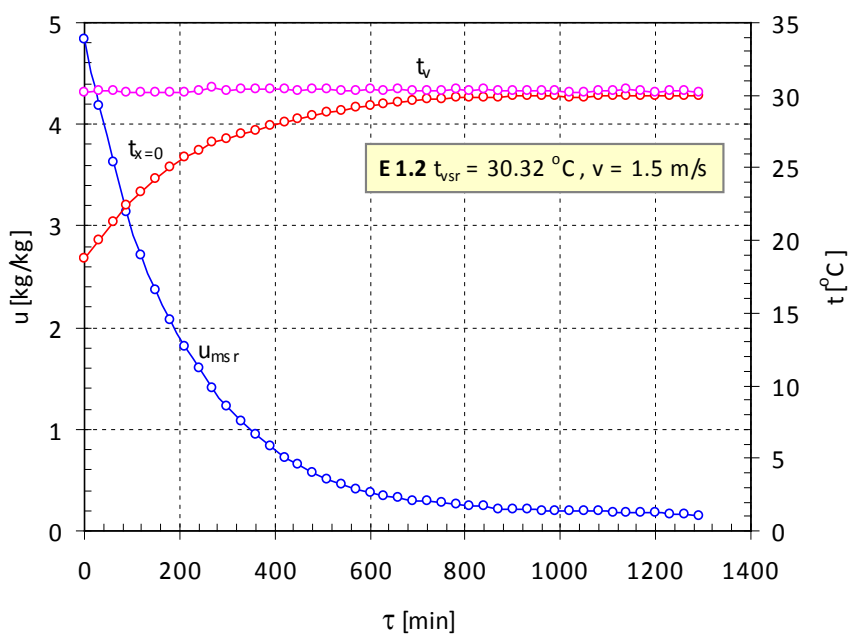

Fig.4. Experiment E1.2

On the other hand, same parameters for one of performed experiments for convective drying kinetics experiments of quince pieces are shown in Figure 5.

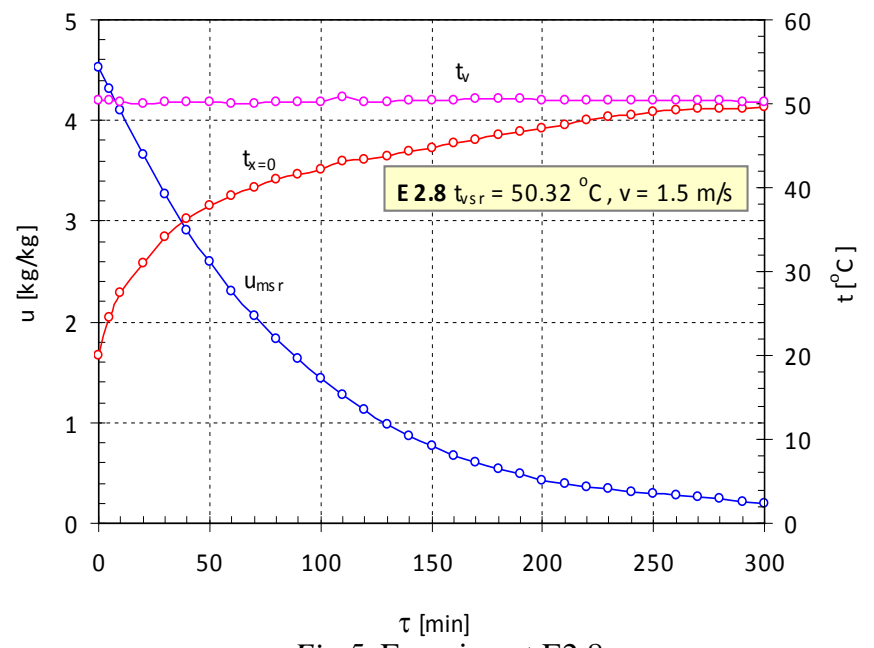

Fig.5. Experiment E2.8 
The temperature response $t(x=0, \tau)$, or the measured temperatures vector which is obtained as an arithmetic average value from the temperatures measured using three microthermocouples for each of the time steps from the experiments of convective drying are performed previously.

$\mathrm{t}\left(x=0, \tau_{i}\right)=\frac{1}{3} \sum_{j=1}^{3} t j\left(x=0, \tau_{i}\right) \quad i=1, i \max$

\section{CONCLUSIONS}

The main idea in this paper was to replace the time consuming and inaccurate measurements for determination of equilibrium moisture content, obtained with the static gravimetric method, by accurate and easy to perform single thermocouple temperature measurements in the convective drying kinetics experiments. The resulting temperature response from the conducted experiments can be successfully used to determine unknown parameters in the models for calculation of the equilibrium moisture content, by applying of inverse approach method that is an essential tool in modeling of heat and mass transfer processes for different food materials.

In order to see the impact of each of the determined parameters on the accuracy of calculations for drying process when the model is incorporated in the mathematical variable boundary model, or when it is used only for approximation of experimental values of equilibrium moisture content of pear and quince, the relative temperature sensitivity coefficients should be calculated.

\section{REFERENCES}

Aktas, T., Ulger, P., Daglioglu, F., Sahin, F.H. (2014). Sorption isotherms and net isosteric heat of sorption for plum osmotically pre-treated with trehalose and sucrose solutions, Bulgarian Journal of Agricultural Science, 20 (3), 515-522.

Al-Muhtaseb, A.H., McMinn, W.A.M., Magee, T.R.A. (2004). Water sorption isotherms of starch powders: part 1: Mathematical description of experimental data. Journal of Food Engineering, 61(3), 297-307.

Barroca, M.J., Guiné, R.P.F., Ferreira D.M.S., Gonçalves, F.M. (2005). Sorption isotherms of portuguese varieties of pears, $7^{\circ}$ Encontro de Química dos Alimentos, 13-16 Abril, Viseu ESAV - IPV / SPQ, P3.8, 7 pag, ViseuCaurie, M., 2007, Hysteresis phenomenon in foods. Food Science and Technology, 42 (1), 45- 49.

Blahovec, J., Yanniotis, S. (2009). Modified classification of sorption isotherms. Journal of Food Engineering, 91 (1), 72 77.

Djendoubi, M.N., Bonazzi, C., Courtois, F., Boudhrioua, N., Kechaou, N. (2011). Moisture desorption isotherms, isosteric heats of desorption and glass transition of fresh pear and apple: Experimental and mathematical investigation, $3^{\text {th }}$ European Drying Conference-EuroDrying'2011, Palma, Balearic Island, Spain, 26-28 October, 1-4.

Djendoubi, M.N., Boudhrioua, M. N., Kechaou, N., Courtois, F., Bonazzi, C. (2013). Effect of Osmo-dehydration Conditions on the Quality Attributes of Pears. Journal of Food processing and Technology, 4 (8). 256-261.

Falade, K.O., Adetunji, A.I., Aworh, O.C. (2003). Adsorption isotherm and heat of sorption of fresh- and osmo-oven dried plantain slices. European Food Research Technology, 217 (3), 230-234.
Gal, S. (1981). Recent developments in techniques for obtaining complete sorption isotherms, in: Water activity: Influence on food quality, Rockland, L.B. and Beuchat, L.R. (eds.), Academic Press, New York, 89-110.

Goula, A.M., Karapantsios, T.D., Achilias, D.S., Adamopoulos, K.G. (2008). Water sorption isotherms and glass transition temperature of spray dried tomato pulp. Journal of Food Engineering, 85 (1), 73-83.

Greenspan, L. (1977). Humidity Fixed Points of Binary Saturated Aqueous Solutions. Journal of Research of National Bureau of Standards - A Physics and Chemistry, 81A (1977), 1, 89-96

Guiné, R.P.F., Castro, J.A.A.M. (2002). Experimental determination and computer fitting of desorption isotherms of D. Joaquina pears, Food and Bioproducts Processing, 80 (3), 149-154.

Kaya, A., Aydin, O., Demirtas, C., Akgün, M. (2007). An experimental study on the drying kinetics of quince, Desalination, 212 (1 and 3), 328-343.

Kaymak-Ertekin, F., Gedik, A. (2004). Sorption isotherms and isosteric heat of sorption of grapes, apricots, apples and potatoes, LWT-Food Science and Technology, 37 (4), 429438.

Kiranoudis, C.T., Maroulis, Z.B., Tsami, E., Marinos-Kouris, D. (1993a). Equilibrium moisture content and heat of desorption of some vegetables. Journal of Food Engineering, 20 (1), 55-74.

Lahsasni, S., Kouhila, M., Mahrouz, M., Kechaou, N. (2002). Experimental study and modeling of adsorption and desorption isotherms of prickly pear peel (Opuntia ficus indica), Journal of Food Engineering, 55 (3), 201-207.

Lahsasni, S., Kouhila, M., Mahrouz, M., Fliyou, M. (2003). Moisture adsorption-desorption isotherms of prickly pear cladode (Opuntia ficus indica) at different temperatures, Energy Conversion and Management, 44 (6), 923-926.

Lahsasni, S., Kouhila, M., Mahrouz, M. (2004). Adsorptiondesorption isotherms and heat of sorption of prickly pear fruit (Opuntia ficus indica), Energy Conversion and Management, 45(2), 249-261.

Lutovska, M., Mitrevski, V., Geramitcioski T., Mijakovski, V. (2014). Review of journals with particular emphasis on papers in which sorption isotherms were determined. Journal on Processing and Energy in Agriculture, 18 (1), 25-29.

Lutovska, M., Mitrevski, V., Geramitcioski, T., Mijakovski, V., Andreevski, I. (2016). Water activity vs. equilibrium moisture content. Journal on Processing and Energy in Agriculture, 20 (2), 69-72.

Lutovska, M., Mitrevski, V., Pavkov, I., Mijakovski, V., Radojcin, M., S. (2016a). Mathematical modeling of thin layer drying of pear, Chemical Industry \& Chemical Engineering Quarterly, 22 (2), 191-199, impact factor 0.617- Thomson Reuters.

Maroulis, Z.B., Tsami, E., Marinos-Kouris, D. (1988), Application of the GAB model to the moisture sorption isotherms for dried fruits. Journal of Food Engineering, 7 (1), 63-78.

Mitrevski, V., Lutovska, M., Mijakovski, V. (2014). Eksperimentalno istrazuvanje na kinetikata na susenje na krusa vo tenok sloj, Zbornik na trudovi, Tehnicki fakultet Bitola, Bitola.

Mitrevski, V., Lutovska, M., Mijakovski, V., Pavkov, I., Babic, M., Radojcin, M. (2015a). Adsorption isotherm of pear at 
several temperatures, Thermal Science Journal, 19 (3), 11211131.

Mitrevski, V., Lutovska, M., Mijakovski, V., Pavkov, I., Mitrevska, C. (2015b). Experimental investigation and mathematical modeling of thin layer drying of quince, $5^{\text {th }}$ European Drying Conference, 21-23 October, Budapest, Hungary.

Moreira, R., Chenlo, F., Torres, M.D., Vallejo, N. (2008). Thermodynamic analysis of experimental sorption isotherms of loquat and quince fruits. Journal of Food Engineering, 88 (4), 514-521.

Mulet, A., Garcia-Reverter, J., Sanjuán, R., Bon, J. (1999), Sorption isosteric heat determination by thermal analysis and sorption isotherms. Journal of Food Science, 64 (1), 64-68.

Noshad, M., Shahidi, F., Mohebbi, M., Mortazavi, S.A. (2013). Desorption isotherms and thermodynamic properties of fresh and osmotic-ultrasonic dehydrated quinces. Journal of Food Processing and Preservation, 37 (5), 381-390.

Pavkov, I. (2012). Kombinovana tehnologija sušenja voćnog tkiva, doktorska disertacija.

Rahman M.S., Sablani, S.S. (2009). Water activity measurement methods of foods, in: Rahman M.S., (eds.), Food Properties Handbook, 9-32, CRC Press, New York.

Roman, G.N., Urbicain, M.J., Rotstein, E. (1982). Moisture equilibrium in apples at several temperatures: Experimental data and theoretical considerations, Journal of Food Science, 47 (5), pp. 1484-1488.
Saravacos, G.D., Tsiourvas, D.A., Tsami, E. (1986). Effect of temperature on the water adsorption isotherms of Sultana raisins. Journal of Food Science, 51 (2), 381-383.

Shivhare, U.S., Arora, S., Ahmed, J., Raghavan, G.S.V. (2004). Moisture adsorption isotherms for mushroom, LWT-Food Science and Technology, 37 (1), 133-137.

Spiess, W.E.L., Wolf, W. (1987). Water Activity: Theory and applications to Food, in: Rockland, L.B. and Beuchat, L.R. (eds.), Marcel Dekker, Inc., New York.

Tsami, E., Marinos-Kouris, D., Maroulis, Z.B. (1990). Water sorption isotherms of raisins, currants, figs, prunes and apricots, Journal of Food Science, 55 (6), 1594-1597.

Veltchev, Z.N., Menkov, N.D. (2000). Desorption isotherms of apples at several temperatures, Drying Technology 18 (4 and 5), 1127-1137.

Weisser, H. (1985). Influence of temperature on sorption equilibria, in: Simatos, D. and Multon, J.L. (eds.) Properties of water in Foods, NATO ASI Series, Series E: Applied Sciences - No. 90, Dordrecht, 95-118.

Wolf, W., Spiess, W.E.L., Jung, G. (1985). Standardization of isotherm measurements (COST-Project 90 and 90 bis), In: Simatos, D., Multon, J.L., (eds.), Properties of water in foods, Martinus Nijhoff Publishers, Dordrecht, The Netherlands, 661679.

Received: 26. 02. 2017.

Accepted: 06. 04. 2017. 